\title{
Wound dressings for a proteolytic-rich environment
}

\author{
Andreia Vasconcelos • Artur Cavaco-Paulo
}

Received: 30 November 2010 /Revised: 17 January 2011 / Accepted: 17 January 2011 / Published online: 1 March 2011

(C) Springer-Verlag 2011

\begin{abstract}
Wound dressings have experienced continuous and significant changes over the years based on the knowledge of the biochemical events associated with chronic wounds. The development goes from natural materials used to just cover and conceal the wound to interactive materials that can facilitate the healing process, addressing specific issues in non-healing wounds. These new types of dressings often relate with the proteolytic wound environment and the bacteria load to enhance the healing. Recently, the wound dressing research is focusing on the replacement of synthetic polymers by natural protein materials to delivery bioactive agents to the wounds. This article provides an overview on the novel protein-based wound dressings such as silk fibroin keratin and elastin. The improved properties of these dressings, like the release of antibiotics and growth factors, are discussed. The different types of wounds and the effective parameters of healing process will be reviewed.
\end{abstract}

Keywords Wound healing · Silk fibroin · Collagen · Elastin · Keratin

\section{Introduction}

In the past, traditional dressings such as plant fibers, honey and animal fat were used to cover the wound, keeping it dry by allowing the evaporation of wound exudate and preventing the entry of harmful bacteria into the wound.

\footnotetext{
A. Vasconcelos $\cdot$ A. Cavaco-Paulo $(\bowtie)$

Departamento de Engenharia Têxtil, Campus de Azurém,

Universidade do Minho,

4800-058 Guimarães, Portugal

e-mail: artur@det.uminho.pt
}

Nowadays, the development of new biopolymers and fabrication techniques creates wound dressings with improved properties that enhance the healing process. Effective wound management requires the understanding of the type of wound and healing process. The physical, mechanical and chemical properties of the dressing must also be taken into consideration. The new biomaterials to be applied as wound dressings should create a moist environment around the wound, effective oxygen circulation, cellular guidance and low bacterial load. This review discusses the basic principles of wound healing, type of wounds and the type of wound dressings. An overview will be given on the properties of fibrous proteins and their characteristics as wound dressings.

\section{Wounds and wound healing process}

A wound, according to the Wound Healing Society, is the result of "disruption of normal anatomic structure and function" (Lazarus et al. 1994). Based on the nature of the repair process, wounds can be classified in acute wounds and chronic wounds. Acute wounds usually heal completely within $8-12$ weeks with minimal scarring (Nicholas 2002). The primary causes of acute wounds include mechanical injuries and burns.

Chronic wounds fail to heal in the expected time frame and persist beyond 12 weeks, with the possibility to reoccur (Harding et al. 2002). A chronic wound does not heal properly because the orderly sequence of events is disrupted at one or more stages of the healing. The factors that inhibited or negatively influence the healing can be divided into systemic and local (Table 1). A chronic wound is usually a permanent inflammatory state comprising a high and constant proteolytic activity. This will diminish the recognition and subsequent removal of cells by macro- 
Table 1 Factors that inhibit wound healing (Enoch and Leaper 2008; Thomas et al. 2010)

\begin{tabular}{ll}
\hline Local factors & Systemic factors \\
\hline Scalds and burns (physical and chemical) & Advanced age and immobility \\
Local pressure & Obesity \\
Compromised vascular perfusion (arterial, venous or mixed) & Malnutrition and nutritional deficiencies \\
Neurologic defects & Systemic malignancy and terminal illness \\
Inadequate blood supply & Immunodeficiency \\
Poor venous drainage & Trauma (initial or repetitive) \\
Foreign body and foreign body responses & Chemotherapy and radiotherapy \\
Infection & $\begin{array}{c}\text { Immunosuppressive drugs, corticosteroids } \\
\text { and anticoagulants }\end{array}$ \\
Excess local mobility & $\begin{array}{c}\text { Psychosocial stress } \\
\text { Underlying osteomyelitis }\end{array}$ \\
& $\begin{array}{l}\text { Systemic diseases (diabetes, rheumatoid } \\
\text { arthritis, connective tissue diseases, } \\
\text { metabolic diseases) }\end{array}$ \\
Malignant transformation (Marjolin's ulcer) & $\begin{array}{l}\text { Inherited neutrophil disorders } \\
\text { Impaired macrophage activity }\end{array}$
\end{tabular}

phages promoting a necrotic disintegration. Chronic wounds include decubitus wounds (pressure sores); venous, arterial and diabetic foot ulcers; and wounds due to autoimmune disease. Although chronic wounds are a clinical and economic burden, there has been little consensus on how to diagnose and treat them (Kuehn 2007).

\section{Principles of wound healing}

Wound healing is a specific biological process related to the general phenomenon of growth and tissue regeneration. There are several reports describing the various biological and physiological stages of healing (Boateng et al. 2008; Queen et al. 2004; Strodtbeck 2001). The wound healing process can be summarized into five independent and overlapping stages, including hemostasis, inflammation, migration, proliferation and maturation (Fig. 1). The healing process is not linear and can progress forward and backwards through the phases depending on various factors.

Hemostasis and inflammation occurs soon after the damage of the skin, which is often accompanied by bleeding. This activates hemostasis through fibrinogen that leads to the coagulation of exudates (blood without cells and platelets) and, together with the formation of a fibrin network, produces a clot in the wound that stops the bleeding and provides a temporary matrix for cellular migration. Inflammation occurs almost simultaneously with hemostasis, from within a few minutes to $24 \mathrm{~h}$ and lasts for about 3 days, involving the infiltration of the wound with polymorphonuclear leukocytes (neutrophil granulocytes) whose main function is to minimize bacterial contamination of the wound preventing infection. At later stages of inflammation, macrophages are the most important cells being the principal producer of growth factors responsible for the proliferation.

Migration and proliferation involves the movement of epithelial cells and fibroblasts to the injured area to replace damaged and lost tissue. These cells regenerate from the margins, rapidly growing over the wound under the clot followed by deposition of the extracellular matrix. With the progression of the proliferative phase, the temporary fibrin/ fibronectin matrix is replaced by the newly formed granulation tissue and collagen synthesis.

Maturation is also named the remodeling phase and involves the formation of cellular connective tissue and strengthening of the new epithelium, which determines the nature of the final scar. There is continuous synthesis and breakdown of collagen as the extracellular matrix is constantly remodeled, equilibrating to a steady state after approximately 21 days after wounding.

The most important cells involved in the various steps of wound healing are summarized in Table 2.

\section{Proteolytic and microbiological environment of wounds}

Wounds, acute or chronic, are characterized by the production of fluid, exudate, which is a key component in all stages of wound healing, irrigating the wound continuously and keeping it moist (Gray and White 2004). Exudate supplies nutrients and leukocytes to the wound, which helps control bacteria and infection. In chronic wounds, there is excessive amount of exudate that can cause maceration of healthy tissue around the wound (Cutting and White 2002). In addition, exudate from chronic wounds differs from that of acute wounds with relatively higher levels of tissue destructive proteases, namely metalloproteinases (MMPs) 


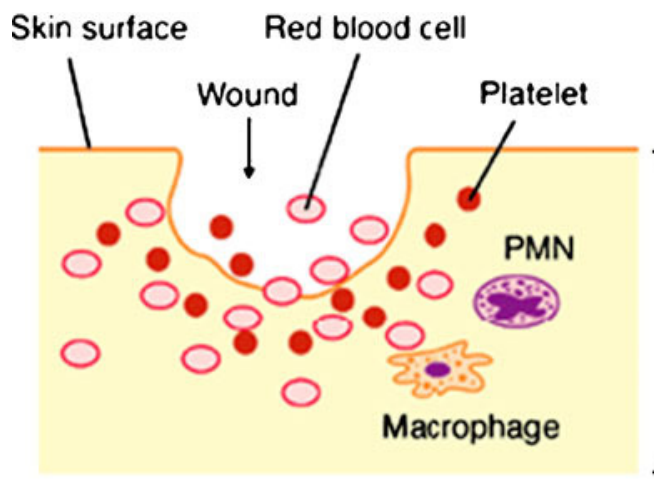

a Injury

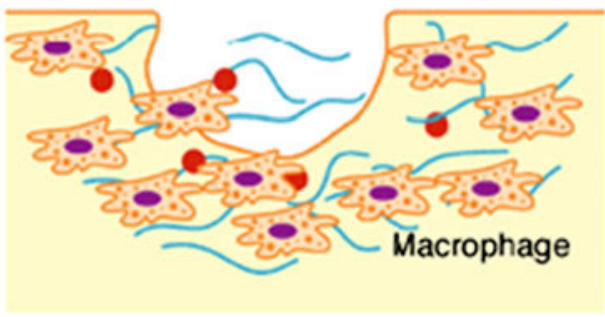

d Late inflammation (48 h)

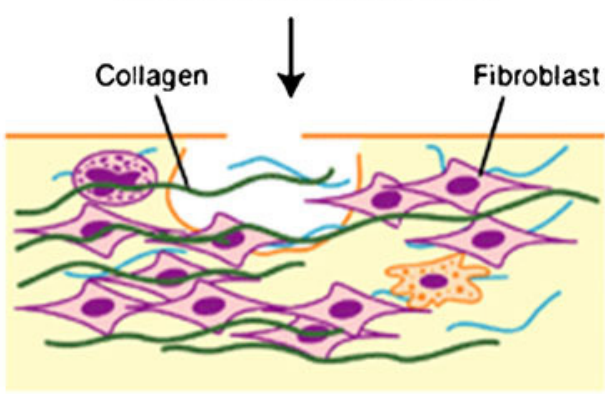

e Proliferation (72 h)

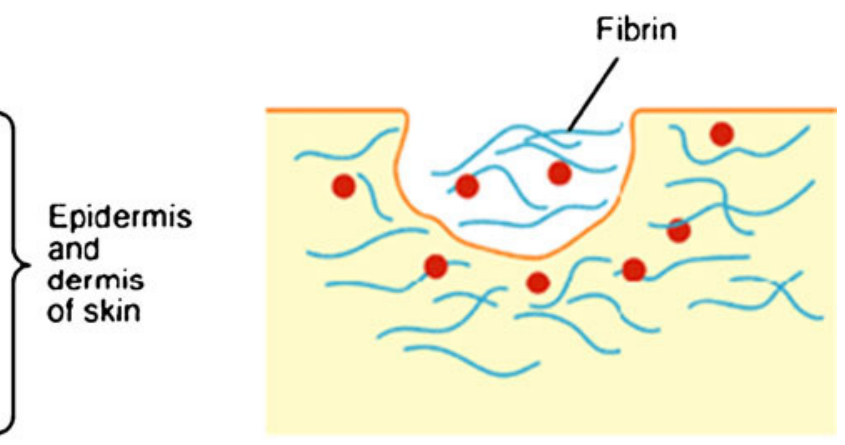

b Coagulation

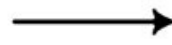

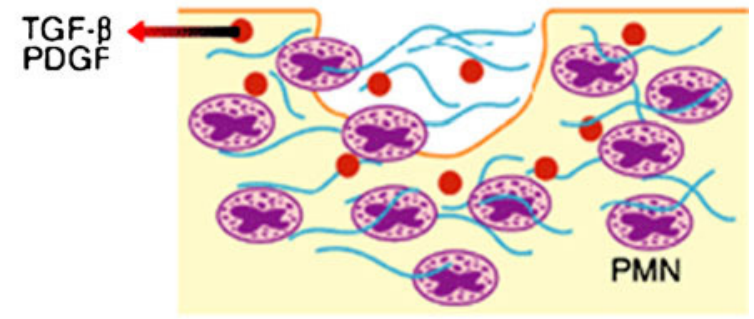

c Early inflammaton (24 h)

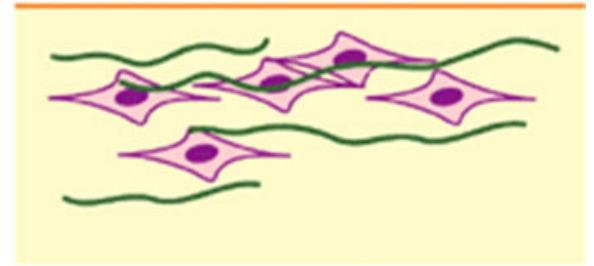

f Remodelling (weeks to months)

Fig. 1 Phases of cutaneous wound healing (adapted from Strodtbeck 2001)

and polymorphonuclear elastase (Chen et al. 1992). Exudate obtained from chronic wounds has been shown to contain human neutrophil elastase, cathepsin G, urokinase-type plasminogen activator and gelatinase (MMP-9; Chen et al. 1992; Cutting and White 2002).

A wound often provides a moist, warm and nutritious environment to microbial colonization and proliferation. The number and diversity of microorganisms will depend on the type of wound, depth, location and the antimicrobial efficacy of the host immune response. Wound colonization is most frequently polymicrobial (Bowler 1998; Bowler and Davies 1999; Bowler et al. 2001), involving numerous microorganisms that are potentially pathogenic, which may lead to infection. When infection is present, the wound fails to heal, and there is increased trauma to the patient and increased treatment costs. Infection should be considered if one of the following is present: pyrexia, increased pain, increasing erythema of surrounding skin, lymphangitis and rapid increase in wound size (Douglas and Simpson 1995). Nevertheless, since chronic wounds may not always display the classic symptoms of infection, signs such as serous exudate plus concurrent inflammation, delayed healing, discoloration of granulation tissue, friable granulation tissue, foul odor and wound breakdown should also be used to identify infection (Gardner et al. 2001).

It is widely recognized that aerobic or facultative pathogens such as Staphylococcus aureus, Pseudomonas aeruginosa and $\beta$-hemolytic streptococci are the primary causes of infection of both acute and chronic wounds (Daltrey et al. 1981; Halbert et al. 1992; Sehgal and Arunkumar 1992). However, the distinction between infected and colonized wounds has to be done on a clinical 
Table 2 Type of cells involved in the wound healing process

\begin{tabular}{ll}
\hline Cell type & Function in wound healing \\
\hline Platelets & Involved in thrombus formation \\
& Rich source of inflammatory mediators including cytokines \\
& Major initial stimulus for inflammation \\
& First cells to infiltrate the wound \\
Neutrophils & Phagocytosis and intracellular killing of invading bacteria \\
& Phagocytosis and killing of invading bacteria \\
Monocytes (macrophages) & Clear debris and necrotic tissue \\
& Rich source of inflammatory mediators including cytokines \\
& Stimulate fibroblasts division, collagen synthesis and angiogenesis \\
Not clearly defined & May produce cytokines in certain types of wounds \\
Fibroblasts & Produce various components of the ECM including collagen, \\
& fibronectin, hyaluronic acid, proteoglycans \\
Synthesized granulation tissue
\end{tabular}

perspective instead of microbiological analysis due to the universal colonization of chronic wounds. This frequently presents a wrong diagnosis that leads to the unnecessary use of antibiotics.

\section{Wound dressings}

The wound requires a protective barrier to promote the healing. Early humankind employed many different materials from the natural surroundings to treat the wounds. These include natural fibers such as wool and linen, honey, eggs and animal fat (Inngjerdingen et al. 2004; Mensah et al. 2006). Continuous development results in the development of wound dressings with improved performance. Wound dressings can be classified covering different aspects (Sai and Babu 2000; Thomas 2004) as follows:

1. Passive dressings such as gauze and tulle that act to cover the wound. Gauze can stick to the wound and disrupt the wound bed when removed, thus are suitable for minor wounds. Tulle is as greasy gauze suitable for minimal to moderate exudates.

2. Interactive dressings contain polymeric films, foams and hydrogels which are transparent and permeable to water and atmospheric oxygen. These are suitable for heavily exudating wounds (foams and hydrogels) and good barriers against permeation of bacteria to the wound environment.

3. Bioactive dressings such as hydrocolloids, alginates, collagen and hydrofibers produced from a variety of biopolymers such as collagen, hyaluronic acid, chitosan, alginate and elastin (Falabella 2006; Queen et al. 2004). These types of dressings have the ability to modify facing the physiological condition of the wound, promoting the healing. The bioactive dressings normally contain active ingredients such as antimicrobials and antibiotics (Queen et al. 2004) or can target the reduction of high protease levels on the wound (Cullen et al. 2002; Vachon and Yager 2006). Depending on the wound type and its healing, one or more different types of dressings can be applied. Table 3 describes the desirable properties of wound dressings and their impact on the healing process.

Considering the above characteristics, biomaterials have soon been used as wound dressing materials. They are designed to have an impact in the local wound environment beyond moisture management. Herein, the characteristics of protein-based materials and their action on the wound healing will be described.

\section{Commercial protein-based wound dressings}

\section{Collagen}

The development of collagen wound dressings is a consequence of its structural and functional significance in wound healing process. Collagen is the most abundant protein of extracellular matrix (ECM) providing support to connective tissues such as skin, tendons, bones, cartilage, blood vessels and ligaments (Eyre 1980; Lee et al. 2001a; Wong Po Foo and Kaplan 2002). It constitutes 30\% of all protein found in the body acting as a natural scaffold for cell attachment, migration, proliferation, differentiation and survival (Yang et al. 2004). Collagen possesses high mechanical strength, good biocompatibility, low antigenicity, biodegradability, and the ability to promote cellular attachment and growth, which makes this a valuable protein for 
Table 3 Properties of wound dressings and their impact on healing

\begin{tabular}{|c|c|}
\hline Properties & Impact on wound healing \\
\hline $\begin{array}{l}\text { Debridement (wound } \\
\text { cleansing) }\end{array}$ & $\begin{array}{l}\text { Enhances migration of leukocytes into the wound bed } \\
\text { Supports accumulation of enzymes }\end{array}$ \\
\hline Provide and maintain moist & $\begin{array}{l}\text { Prevents desiccation and cell death } \\
\text { Promotes epidermal migration, angiogenesis and } \\
\text { connective tissue synthesis } \\
\text { Supports autolysis by rehydration of desiccated tissue }\end{array}$ \\
\hline $\begin{array}{l}\text { Absorption (blood and } \\
\text { excess of exudate) }\end{array}$ & $\begin{array}{l}\text { Excessive exudate blocks the proliferation and cellular activity } \\
\text { and degrades connective tissue, factors that delay the healing } \\
\text { Causes maceration of healthy tissue surrounding the wound }\end{array}$ \\
\hline Permeable (water, vapor, air) & $\begin{array}{l}\text { Permeability to water vapor controls the management of exudate } \\
\text { Low tissue oxygen levels stimulate angiogenesis } \\
\text { High tissue of oxygen stimulates ephitelialization and fibroblasts }\end{array}$ \\
\hline Bacterial barrier & $\begin{array}{l}\text { Infection prolongs the inflammatory phase and delays collagen } \\
\text { synthesis, inhibits epidermal migration and induces additional } \\
\text { tissue damage }\end{array}$ \\
\hline Provide thermal insulation & $\begin{array}{l}\text { Normal tissue temperature improves the blood flow } \\
\text { to the wound bed and enhances epidermal migration }\end{array}$ \\
\hline Low adherence & $\begin{array}{l}\text { Adherent dressings may be painful and difficult to } \\
\text { remove causing further tissue damage }\end{array}$ \\
\hline
\end{tabular}

biomedical applications (Lee et al. 2001a). Furthermore, the abundance of functional groups along the collagen polypeptide backbone allows the incorporation of genes, growth factors and other biological molecules (Harley and Gibson 2008).

Collagen sutures and extrude fibers were used to cover the exposed areas of wounded skin during the Second World War. Since then, collagen has been extensively applied for the development of wound dressings. Collagen films are made by casting collagen solutions onto methacrylate surfaces, which are thin and difficult to handle; thus, cross-linking is necessary. UV irradiation increased the mechanical strength of the films, and when implanted in animals, a very mild inflammatory response was observed along with fibroblast attachment to the collagen surface (Dunn et al. 1967). Blends of collagen films with nylon and silicon increased the mechanical strength and have been shown to be potential wound dressings exhibiting rapid epithelialization with little inflammatory response (Shettigar et al. 1982; Smith 1995). The incorporation of antimicrobial agents (Man et al. 2007) and antioxidants (Gopinath et al. 2004) on collagen films was released in a controlled manner, promoting the wound healing.

Collagen sponges are normally produced by lyophilization of collagen gel dispersions or acidic solutions (Zhong et al. 2010). These are suitable platforms for wound dressings because the large pores and interconnectivity enhances in vitro cellular attachment and growth and promote wound tissue infiltration in vivo (Doillon 1987). As advantages, collagen sponges often have poor biostability and low mechanical strength, and wound contraction easily occurs
(Auger et al. 1998; Berry et al. 1998; Ono et al. 1999). Extensive modifications by cross-linking (Garcia et al. 2008; Powell and Boyce 2007) or blending with other natural and synthetic polymers such as ECM components (Ding et al. 2008; Doillon et al. 1987; Ruszczak 2003), chitosan (Man et al. 2007; Wang et al. 2008a), polycaprolactone (Dai et al. 2004; McClure et al. 2011), polylactide-polyglycolide (PLGA; Chen et al. 2004, 2006a) and polyurethane (Wu et al. 2003) improved the mechanical properties due to the formation of intra- and intermolecular covalent bonds. Moreover, these collagen-based sponges inhibited the collagen matrix from contracting, accelerating the healing. The incorporation of ECM components such as fibronectin, elastin and glycosaminoglycans (GAGs) are important in guiding the cell physiology and behavior in wound healing (Ding et al. 2008; Doillon et al. 1987; O’Brien et al. 2004; Ruszczak 2003). Addition of growth factors (Ono et al. 1998; Wang et al. 2008a) onto collagen sponges prevents wound contraction by promoting faster wound closure. Recently, the same behavior was observed by the incorporation of a herbal formulation into a collagen sponge, with improved tissue regeneration and collagen content at the wound site (Kumar et al. 2010). The ECM is composed of collagen nanoscale fibers which provide structural integrity and mechanical strength to the skin. Electrospun collagen was found to be the most biomimetic nanofibrous scaffolds similar to the native ECM. Electrospun collagen matrices exhibited excellent biocompatibility and accelerated wound healing, along with inhibition of wound contraction in the early stage of wound healing (Powell et al. 2008; Rho et al. 2006). Moreover, electrospun collagen blends with chitosan 
(Chen et al. 2008) and PLGA (Liu et al. 2010) also showed accelerated wound healing when compared to collagen sponges. There are several commercially available collagen-based wound dressings. Table 4 describes their composition and function observed during wound healing.

\section{Gelatin}

Gelatin is a natural polymer that is derived from collagen and is commonly used for pharmaceutical and medical applications because of its biodegradability (Balakrishnan and Jayakrishnan 2005; Ikada and Tabata 1998; Kawai et al. 2000; Yamamoto et al. 2001) and biocompatibility in physiological environments (Kuijpers et al. 2000; Yao et al. 2004). Due to its easy processability and gelation properties, gelatin has been manufactured in a range of shapes including sponges, injectable hydrogels and gelatin microspheres which normally are incorporated in a second scaffold such as a hydrogel.

Gelatin has been applied as a dressing showing improved wound healing. Cationized gelatin hydrogel incorporating growth factors was applied to the round corneal defects in rabbits (Hori et al. 2007). This resulted in a reduction in the epithelial defect in rabbit corneas accompanied by a significantly enhanced epithelial proliferation with accelerated ocular surface wound healing. In a similar study, gelatin sponges incorporating growth factor were used to treat pressure-induced decubitus ulcers (Jiang et al. 2008; Kawai et al. 2005). It was shown that the release of growth factors promotes accelerated wound healing and induces neovascularisation. A bilayer wound dressing prepared from gelatin sponges and elastomeric polyurethane membranes were used for the incorporation of epidermal growth factor (EGF; Huang et al. 2006; Ulubayram et al. 2001). The prepared systems were tested in vivo experiments on full-thickness skin defects created on rabbits with no foreign body reaction.

The release of antimicrobials agents such as catechol (Adhirajan et al. 2009), cyclic adenosine monophosphate which is a second messenger and regulator of human keratinocyte proliferation (Balakrishnan et al. 2006) had been shown to avoid wound infection and promoted accelerated healing and re-epithelialization of fullthickness wounds. Gelatin blends with alginate (Balakrishnan et al. 2005) applied to full-thickness wounds showed the formation of new skin; chitosan (Deng et al. 2007) has been shown to have antimicrobial properties with improved mechanical properties (Yang et al. 2011). A bilayer gelatin/ chondrointin-6-sulfate/hyaluronic acid dressing grafted to the dorsum of mice has positive effect on promoting wound healing, but also has a high rate of graft take (Wang et al. 2006). Electrospun gelatin and poly(L-lactide) (Gu et al. 2009) and gelatin/fibrinogen (Dainiak et al. 2011) showed controlled evaporative water loss and promoted fluid drainage ability and excellent biocompatibility, therefore having potential application as wound dressing.

Fibrin

Fibrin is a protein matrix produced from fibrinogen, which can be autologously harvested from the patient (Aper et al. 2007), providing an immunocompatible carrier for the delivery of active biomolecules, especially cells. Polymerized fibrin is a major component of blood clots and plays a vital

Table 4 Commercial collagen-based wound dressings

\begin{tabular}{|c|c|c|}
\hline Dressing & Composition & Application \\
\hline Alloderm ${ }^{\mathrm{TM}}$ & Acellular dermis from cadaveric skin origin & $\begin{array}{l}\text { Autograft in the resurfacing of burn wounds } \\
\text { reconstruction due to its human origin } \\
\text { (Kearney 2001) }\end{array}$ \\
\hline Integra ${ }^{\mathrm{TM}}$ & Bovine tendon collagen and shark GAGs & $\begin{array}{l}\text { Split-thickness skin grafts; treatment of leg ulcers } \\
\text { and wound closure of severe burn wounds } \\
\text { (Fitton et al. 2001) }\end{array}$ \\
\hline Promogram $^{\circledR}$ & $\begin{array}{l}\text { Animal collagen }(55 \%) \text { with oxidized } \\
\text { regenerated cellulose }(45 \%)\end{array}$ & $\begin{array}{l}\text { Absorb excess proteases from the wound surface } \\
\text { (Schönfelder et al. 2005) }\end{array}$ \\
\hline Puraply ${ }^{\circledR}$ & Reconstructed type I porcine collagen & $\begin{array}{l}\text { Partial- and full-thickness wounds including } \\
\text { chronic wounds, donor sites and for MOHS } \\
\text { surgery (Sanjay et al. 2009) }\end{array}$ \\
\hline Fibrocol Plus $^{\circledR}$ & Animal collagen $90 \%$ with an alginate $10 \%$ & $\begin{array}{l}\text { Partial thickness wounds, venous ulcers, } \\
\text { acute traumatic wounds, second degree burns }\end{array}$ \\
\hline Apligraft ${ }^{\mathrm{TM}} /$ Graftskin $^{\mathrm{TM}}$ & Human fibroblasts and bovine tendon collagen gel & $\begin{array}{l}\text { Venous leg ulcers and diabetic foot ulcers } \\
\text { (Curran and Plosker 2002) }\end{array}$ \\
\hline Orcel $^{\mathrm{TM}}$ & $\begin{array}{l}\text { Human epidermal keratinocytes and dermal } \\
\text { fibroblasts) cultured in a type I } \\
\text { bovine collagen sponge }\end{array}$ & Acute surgical excisions (Still et al. 2003) \\
\hline
\end{tabular}


role in the subsequent wound healing response (Neidert et al. 2002). Fibrin naturally contains sites for cell binding and therefore has been investigated as a substrate for cell adhesion, spreading, migration and proliferation (Ehrbar et al. 2005). Fibrin glue is a biological adhesive also used in surgery (abdominal, thoracic, vascular, oral, endoscopic) due to its haemostatic, chemotactic and mitogenic properties (Le Nihouannen et al. 2006). Fibrin glue mimics the last step of the in vivo coagulation cascade through the activation of fibrinogen by thrombin, resulting in a clot of fibrin with adhesive properties (Oju et al. 2005). Fibrinogen is converted into a monomeric form of fibrin by thrombin, forming a clot. The concentration of fibrinogen is $20-40$ times higher in fibrin sealant products than in body fluid. Fibrin provides a material that can be rapidly invaded, remodeled and replaced by cell associated proteolytic activity (Schmoekel et al. 2004). Moreover, due to its biomimetic and physical properties, it is also widely used as a cell carrier to many cell types, such as keratinocytes, urothelium cells, tracheal epithelial cells (Wechselberger et al. 2002), murine embryonic stem cells (Willerth et al. 2006) and mesenchymal progenitor cells (Schantz et al. 2005).

Fibrin is applied as a wound dressing specially because of its sealant properties showing to be effective as an adhesive bandage for treating major renal stab wounds (Griffith et al. 2004; Morey et al. 2001); also, the use of fibrin glue on wound healing in the oral cavity has a positive effect when compared with traditional suture techniques (Baughman et al. 2003; Yücel et al. 2003). The biomechanical strength of skin incision wounds was increased when treated with a fibrin sealant (Jørgensen et al. 1987). Moreover, in vivo wound healing requires fibroblast growth and collagen synthesis, which is stimulated in the presence of fibrin (Michel and Harmand 1990). Wound contraction was also found to be inhibited by the presence of fibrin (Farahani 2007). Fibrin scaffold was used in order to enhance the delivery of adenovirus encoding endothelial nitric oxide synthase (eNOS; Breen et al. 2008). It was shown that fibrin delivery of adenovirus enhanced eNOS expression, inflammatory response and a faster rate of re-epithelialisation. Full-thickness wounds treated with fibrin scaffolds seeded with keratinocytes were shown to promote wound closure (Bannasch et al. 2008) and promote the delivery of epithelial cells that assist wound healing (Grant et al. 2002). Autologuous fibrin sealants produced with commercially available devices $\left(\right.$ CryoSeal ${ }^{\circledR}$ and Vivostat ${ }^{\circledR}$ ) and those industrially produced homologous fibrin sealant Tissucol/Tisseel $^{\circledR}$ were compared in their ability for the formation and stability of clots in an in vitro model mimicking in vivo conditions (diffusion of protease inhibitors and proteolytic digestion; Buchta et al. 2005). It was shown that clot liquefaction occurs faster for all autologous fibrin sealants clots. A novel chimeric protein produced by the fusion of the fibrin-binding domain with epidermal growth factor demonstrated its potential for repairing injured tissues (Kitajima et al. 2009).

\section{Innovative protein-based wound dressings}

\section{Silk fibroin}

Silks are naturally occurring protein polymers produced by a wide variety of insects and spiders (Kaplan et al. 1994, 1998; Vollrath and Knight 2001). The diverse functions of silks range from web construction and prey capture (spider webs), safety lines (draglines) to reproduction (cocoons; Altman et al. 2003; Winkler and Kaplan 2000; Wong Po Foo and Kaplan 2002). Silk in its natural form is composed of a filament core protein, silk fibroin, and a glue-like coating consisting of sericin proteins. The most widely studied silks are cocoon silk from the silkworm Bombyx mori and dragline silk from the spider Nephila clavipes (Jin and Kaplan 2003; Vollrath and Knight 2001). Silk fibers from the domesticated silkworm $B$. mori consist of two proteins - a light chain $(\approx 26 \mathrm{kDa})$ and a heavy chain $(\approx 390 \mathrm{kDa})$ - which are present in a $1: 1$ ratio and are linked by a single disulfide bond that holds the fibroin together (Zhou et al. 2000). These proteins are coated with a family of hydrophilic proteins, sericin (20-310 kDa), which accounts for $25 \%$ of the silk cocoon's mass (Inoue et al. 2000; Kaplan et al. 1998; Zhou et al. 2000). The amino acid composition of silk fibroin from B. mori consists mainly of glycine (Gly, 44\%), alanine (Ala, 29\%) and serine (Ser, 11\%; Vasconcelos et al. 2008). The crystalline domains in the fibers consist of Gly-X repeats, with $\mathrm{X}$ being Ala, Ser, threonine and valine (Val; Zhou et al. 2001). In the solid state, silk fibroin can assume two polymorphs: The silk I structure is water-soluble, and upon exposure to heat, physical spinning and organic solvents easily converts to silk II structure (Jin and Kaplan 2003; Kaplan et al. 1998; Zhou et al. 2001). The $\beta$-sheet structures (silk II) are asymmetrical, with one side occupied by hydrogen side chains from glycine and the other occupied by the methyl side chains from the alanine that populates the hydrophobic domains. Silk II is water-insoluble as well in several solvents, including mild acid and alkaline conditions and several chaotropes.

Silk fibers from $B$. mori have been primarily used in biomedical applications as sutures (Zhang 2002) and, during decades of use, silk fibers proven to be effective in many clinical applications. Nevertheless, immunological reactions observed to virgin silk suture have been attributed to the sericin protein (Moy et al. 1991). It has been shown that sericin is a potential allergen causing a type I allergic reaction (Panilaitis et al. 2003; Rossitch et al. 1987). In this 
way, removal of sericin from silk is necessary to prepare nonallergic and non-cytotoxic silk-based materials. However, a recent study using sericin/gelatin blends for the fabrication of films and sponges reported cytocompatibility using feline fibroblast cells and low immunogenicity (Mandal et al. 2009b).

Silk fibroin-based biomaterials can be obtained with different morphologies: Silk films can be prepared by solvent casting or layer-by-layer deposition of solutions (Hofmann et al. 2006; Huemmerich et al. 2006); SF sponges or scaffolds can be formed after lyophilization, porogens or gas foaming (Wang et al. 2008b); SF hydrogels are formed via sol-gel transitions, sonication, vortexing or the presence of acid and/or ions (Mandal et al. 2009a); SF nanofibers are prepared by electrospinning (Unger et al. 2004); and SF micro/nanospheres have been prepared by water/oil emulsion, spray drying, lipid vesicles, salt leaching and sonication (Hino et al. 2003; Wang et al. 2007). To be further used, it is necessary to induce $\beta$-sheet crystallization so that silk-based materials become water-insoluble and more slowly degraded. This can be achieved through the use of organic solvents such as methanol and formic acid, mechanical stress, high concentrations of salts and thermal treatment (Drummy et al. 2005; Um et al. 2001). Water-based annealing procedure and very slow drying have been shown to induce the formation of the $\beta$-sheet crystal of SF materials (Jin et al. 2005; Lu et al. 2011). According to the US Pharmacopeia, a degradable material is defined as one that "loses most of its tensile strength within 60 days" post-implantation in vivo. By this definition, silk is classified as non-degradable. However, based on the literature, fibroin is proteolytically degradable over longer time periods (Horan et al. 2005). Pure SF and blend systems had been applied in the development of new wound dressing materials, and they have been extensively studied using animal models. Table 5 describes some of the applications of silk fibroin as a wound dressing.

Overall, the healing properties presented by the SF-based materials are related to the physical properties of SF such as water absorption and vapor permeability. The ability to absorb wound exudate forms a flexible dressings that sticks to the wound, preventing excessive flow cell-proliferating substances, exudate and proteins. At the same time, smooth regeneration of the skin is accelerated because the flexible dressings moves when the skin moves, without stimulating the wound

\section{Keratin}

Keratin is the major structural fibrous protein providing outer covering such as hair, wool, feathers, nails and horns of mammals, reptiles and birds (Feughelmann 1985). Keratin fibers, such as wool and human hair, consist of two major morphological parts: the cuticle layer which is composed of overlapping cells that surround the cortex and the inner part of the fiber. Keratin proteins can be roughly classified into two groups: the intermediate filament proteins (IFPs) and the matrix proteins. The most abundant are the IFPs, also known as $\alpha$-keratin, that reside in the fiber cortex. They have an $\alpha$-helical secondary structure, are low in sulfur content and have an average molecular mass in the range of $40-60 \mathrm{kDa}$. The matrix proteins or $\gamma-$ keratin are globular, have low molecular weights and are noted for the high content in either cysteine, glycine or tyrosine residues. The ones with high sulfur content can be divided into high sulfur proteins or ultra-high sulfur proteins depending on their cysteine content and have a molecular weight in the range of $11-26 \mathrm{kDa}$. The high glycine-tyrosine proteins have a molecular weight between 6 and $9 \mathrm{kDa}$. The matrix proteins function to surround the IFPs and interact with them through intermolecular disulfide bonds (Plowman 2003). The formation of the crosslinked IF-matrix composite is crucial in conferring to $\alpha$ keratins their high mechanical strength, inertness and rigidity (Parry and Steinert 1992). There is also another group of keratin proteins, the $\beta$-keratin. These form the majority of the cuticle, and their function is to protect keratin fibers from physical and chemical damage. $\beta$ keratin is difficult to extract and do not form especially useful reconstituted structures (Crewther et al. 1965).

Keratins are extracted from the fibers through the use of chemicals to break the disulfide bonds. The IF and matrix proteins are converted into their non-cross-linked forms by oxidation (Breinl and Baudisch 1907; Buchanan 1977; Crewther et al. 1965; Earland and Knight 1956) or reduction (Crewther et al. 1965; Goddard and Michaelis 1934; Maclaren 1962; O’Donnell and Thompson 1964), during which cysteine is converted to either cysteic acid or cysteine, respectively. Oxidative extraction yields keratins that are hygroscopic, non-disulfide cross-linkable, watersoluble and susceptible to hydrolytic degradation at extremes $\mathrm{pH}$ values due to polarization of the backbone caused by the electron-withdrawing properties of the cysteic acid. These characteristics lead to biomaterials that can degrade relatively fast in vivo, i.e. in the order of days to weeks. Reduced keratins are less polar and, as a consequence, less soluble in water, more stable at extreme $\mathrm{pH}$ and can be re-cross-linked through oxidative coupling of cysteine groups. This results in biomaterials that persist in vivo for weeks to months. The interest of using keratin as a biomaterial in medical applications is based on several key properties that contribute to the overall physical, chemical and biological behaviors of these biomaterials. Extracted keratin proteins have an intrinsic ability to selfassemble and polymerize into fibrous and porous films gels and scaffolds. Furthermore, the presence of cell adhesion 
Table 5 Application of SF as wound dressings

\begin{tabular}{|c|c|c|}
\hline Dressing & Wound & Result \\
\hline PVA/Chitosan/SF (PCS) sponges & Excision rat wound & $\begin{array}{l}\text { Absorption of wound exudate with accelerated } \\
\text { wound healing (Yeo et al. 2000) }\end{array}$ \\
\hline SF films & Full-thickness mice skin wound & $\begin{array}{l}\text { Reduced wound size by } 10 \text {, faster healing about } \\
7 \text { days shorter when compared to control dressing } \\
\text { (DuoActive); higher collagen regeneration and } \\
\text { reduce inflammation (Bidwell et al. 2007) }\end{array}$ \\
\hline SF/alginate sponges & Full-thickness mice skin wound & $\begin{array}{l}\text { Reduced healing time in comparison to control or } \\
\text { pure SF and alginate; significant increase of } \\
\text { re-ephitelialization and in the number of } \\
\text { proliferative cells (Negri et al. 1993) }\end{array}$ \\
\hline $\begin{array}{l}\text { Polarized hydroxyapatite (pHA) } \\
\text { and SF composite gel }\end{array}$ & Full-thickness porcine skin wound & $\begin{array}{l}\text { Higher promotive effects, re-ephitelialization and } \\
\text { matrix formation (Okabayashi et al. 2009) }\end{array}$ \\
\hline $\begin{array}{l}\mathrm{SF} / \text { sericin powder combined } \\
\text { with amorphous SF film }\end{array}$ & NA & Inhibition of edematization (Tsubouchi 2001) \\
\hline SF fiber dressing & NA & $\begin{array}{l}\text { Selective sequestration of targeted proteases from } \\
\text { wound exudate (Mcdevitt 2002) }\end{array}$ \\
\hline Electrospun silk mats & NA & $\begin{array}{l}\text { Loading of electrospun silk mats with EGF } \\
\text { promoted a faster wound closure up to } 90 \% \\
\text { (Schneider et al. 2009) }\end{array}$ \\
\hline SF/chitosan scaffold & Murine soft tissue wound & $\begin{array}{l}\text { Incorporation of human adipose-derived stem } \\
\text { cells (ASCs) onto scaffolds enhanced wound } \\
\text { healing and show differentiation into fibrovascular, } \\
\text { endothelial and epithelial components of } \\
\text { restored tissue (Altman et al. 2003) }\end{array}$ \\
\hline $\mathrm{SF} /$ keratin films & NA & $\begin{array}{l}\text { Incorporation a small inhibitor peptide showed } \\
\text { to reduce elastase activity through the } \\
\text { controlled release of inhibitor from the films } \\
\text { (Vasconcelos et al. 2008) }\end{array}$ \\
\hline
\end{tabular}

sequences, arginine-glycine-aspartic acid and leucineaspartic acid-valine on the keratin protein derived from wool and hair, makes keratin biomaterials able to support cell attachment and growth (Tachibana et al. 2002; Verma et al. 2008). These are the same sequences found in several ECM proteins (Hamasaki et al. 2008; Humphries et al. 1987). In the field of wound healing, several patents have been published using keratin materials as wound-healing promoters (Blanchard et al. 2001, 2000; Cowsar 2003; Van Dyke 2008; Van Dyke et al. 2001a; b). Keratin powder used as an absorbent wound dressing showed the promotion of skin healing due to the release of keratin derivative peptides to the wound (Van Dyke et al. 2001b). Cross-linked keratin powder, films and hydrogels showed significant proliferation of wound healing cell lines like microvascular endothelial cells, keratinocytes and fibroblasts. Moreover, incubation of keratin materials with lymphocytes (T cells) and activated lymphocytes showed, respectively, no proliferation and normal growth, indicating that keratin materials are non-immunogenic and that the body's normal cell-mediated immune response is not inhibited by keratin materials. These were also applied to wounds on animals (rats) and humans, and a faster healing of the wounds treated with keratin materials was observed and, in the human model, with reduced pain (Blanchard et al. 2001, 2000). Water-soluble keratin peptides derived from an oxidative extraction from human hair were shown to be wound-healing agents enhancing the proliferation of human dermal fibroblasts (Van Dyke et al. 2001a). More recently, keratin derivatives obtained either by oxidative and reductive methods were applied to burn wounds using animal and human models. The burn wounds treated with keratin materials showed a decrease in wound size and accelerated wound healing. When applied to bleeding wounds, the keratin materials formed a physical seal of the wound site, providing a porous scaffold for cell infiltration and granulation tissue formation compared to clotted blood (Van Dyke 2008). Keratin was also effectively blended with other components to form new wound dressings. Keratin-collagen sponges were used in rats showing tissue compatibility and accelerated wound healing by stimulating cell proliferation and vascularization (Chen et al. 2006b). An analogue keratin-collagen sponge containing poly 2-hydroxyethylmethacrylate was applied to burn wounds in rats. The composite showed healing promotion by allowing in vivo construction of tissue engineered epidermis (Chen et al. 2007). In another recent study, keratin-gelatin used in full-thickness wounds in dogs 
promoted the healing due to the early presence of hair follicles, sebaceous gland and normal thickness of the epidermis (Thilagar et al. 2009).

\section{Elastin}

Elastin is an ECM protein known for providing elasticity to tissues and organs. As a result, elastin is most abundant in organs that need to stretch and recoil, like blood vessels, elastic ligaments, lungs and skin (Faury 2001; Martyn and Greenwald 2001; Pasquali-Ronchetti and Baccarani-Contri 1997). Elastin is synthesized by a variety of cells, including smooth muscle cells, endothelial cells, fibroblasts and chondrocytes. Elastin is an amorphous protein with about $75 \%$ of hydrophobic amino acid residues (Gly, Ala, Val) and is highly insoluble due to interchain cross-links (Ayad et al. 1994). Elastin is secreted as the precursor tropoelastin ( $\approx 72 \mathrm{kDa}$ ) that is soluble, non-glycosylated and highly hydrophobic (Long and Tranquillo 2003; Madsen et al. 1983; Mecham et al. 1983), which will be further converted into the insoluble elastin polymer. The tropoelastin molecule consists of two types of domains encoded by separate exons: hydrophobic domains with many Gly, Val, Ala and Pro residues which often occur in repeats of several amino acids, like Gly-Val-Gly-Val-Pro, Gly-Val-Pro-Gly-Val and Gly-Val-Gly-Val-Ala Pro, and hydrophilic domains with many Lys and Ala residues that correspond to the potential cross-linking domains of tropoelastin. The two predominant cross-links of native elastin are desmosine and isodesmosine, each involving four Lys residues that are cross-linked by lysyl oxidase. The assembly of tropoelastin into a polymeric matrix is accompanied by the elastin-binding protein $(67 \mathrm{kDa})$ that releases tropoelastin into a pre-formed microfibrillar network, which serves as a scaffold for tropoelastin deposition (Hinek and Rabinovitch 1994; Hinek et al. 1988; Rosenbloom et al. 1993; Ross and Bornstein 1969). The lysine residues become further modified by lysyl oxidase, allowing cross-linking into a stable polymeric matrix.

Elastin can be used in biomaterials in different forms including insoluble elastin, occurring in autografts, allografts and xenografts, decellularized extracellular matrix and in purified elastin preparations. By synthetic or recombinant techniques, repeated elastin-like sequences had also been used in biomaterials. Soluble elastin is obtained from the hydrolysis of insoluble elastin with oxalic acid or potassium hydroxide (Jacob and Robert 1989; Partridge et al. 1955). These treatments will not release tropoelastin from insoluble

Table 6 Application of elastin-based wound dressings to different types of wounds

\begin{tabular}{|c|c|c|}
\hline Dressing & Wound & Result \\
\hline Collagen scaffolds coated with elastin & Full-thickness skin wound & $\begin{array}{l}\text { Improved dermal regeneration and reduce } \\
\text { wound contraction (De Vries et al. 1995) }\end{array}$ \\
\hline Collagen scaffolds coated with elastin & Porcine excision wound & $\begin{array}{l}\text { Reduced wound contraction, improved tissue } \\
\text { regeneration and absence of myofibroblasts } \\
\text { when compared to control (Lamme et al. 1996) }\end{array}$ \\
\hline Collagen/elastin dermal substitute & Porcine excision wound & $\begin{array}{l}\text { Fibroblasts proliferation and reduced migration } \\
\text { of unwanted subcutaneous fibroblasts into the } \\
\text { wound; reduced degradation of the implanted } \\
\text { dermal substitute (Lamme et al. 1998) }\end{array}$ \\
\hline Collagen/elastin membranes & Rat excision wound & $\begin{array}{l}\text { Serves as a template for the formation of } \\
\text { neo-dermis (Hafemann et al. 1999) }\end{array}$ \\
\hline Collagen/elastin dermal substitute & Clinical trial & $\begin{array}{l}\text { Skin elasticity was improved (Cullen et al. 2002; } \\
\text { Hinek et al. 2005) and other parameters like rete } \\
\text { ridges, basement membrane maturation and } \\
\text { epidermal thickness were also improved } \\
\text { (van Zuijlen et al. 2002). }\end{array}$ \\
\hline Alginate/hybrid elastin-derived peptides & $\begin{array}{l}\text { Rabbit ear skin defect } \\
\text { wound model }\end{array}$ & $\begin{array}{l}\text { Promotion of attachment of human dermal } \\
\text { fibroblasts; significantly greater ephitelialization } \\
\text { and a larger volume of regenerated tissue } \\
\text { (Hashimoto et al. 2004) }\end{array}$ \\
\hline Elastin proteolytic digested & Skin of nude mice & $\begin{array}{l}\text { Enhanced elastic fiber deposition and synthesis } \\
\text { (Hinek et al. 2005). }\end{array}$ \\
\hline $\begin{array}{l}\text { Matriderm }{ }^{\circledR} \text { collagen/elastin } \\
\text { commercial dressing }\end{array}$ & Hand burns and joint-associated defects & $\begin{array}{l}\text { Dermal substitute for the treatment of severe } \\
\text { hand burns (Haslik et al. 2007) and for the } \\
\text { reconstruction of joint-associated defects } \\
\text { (Haslik et al. 2010). Full range of motion } \\
\text { was achieved in both cases with no } \\
\text { blisters and scars. }\end{array}$ \\
\hline
\end{tabular}


elastin, but will break peptide bonds, yielding soluble fragments of elastin and leaving the cross-links intact (Jacob and Robert 1989; Partridge et al. 1955). It has been shown that elastin-soluble peptides influence signaling, chemotaxis, proliferation and protease release via the elastin receptor (Duca et al. 2004). Therefore, biomaterials containing solubilized elastin may exert biological effects like increasing elastin synthesis. The self-assembly behavior of elastin was used to obtain different biomaterials like hydrogels (Mithieux et al. 2004; Wright et al. 2002), films (Daamen et al. 2007), nanoparticles (Herrero-Vanrell et al. 2005), sponges (Bellingham et al. 2003) and nanoporous materials (Reguera et al. 2004). These forms can be further applied in cellular orientation, small-diameter blood vessels and drug or growth factor delivery systems. Elastin-like polymers and hybrids of the same with other proteins have been extensively studied. These offer the possibility to produce an assortment of biomaterials with specific functions like manipulation of the transition temperature (Urry 1997) and high-molecular-mass polymers (Lee et al. 2001b, c; Wood et al. 1986). Elastin-based materials have been applied as skin substitutes to treat burn or chronic wounds. Table 6 presents some examples of elastin-based dressings applied to different types of wound models.

As a final remark, the use of collagen and elastin for the development of biomaterials and wound dressings leads to minor failures because these proteins will mimic their function as ECM. On the other hand, using fibrous proteins such as silk fibroin and keratin, due to their place in nature, one would not expect that they could be such valuable materials. Silk fibroin and keratin are characterized by highly repetitive amino acid sequences that result in the formation of relatively homogeneous secondary structures via self-assembly. The ability of these proteins to selfassemble into various physical states was exploited for the development of new biomaterials. These have been shown to undergo materials with improved mechanical strength, control of morphology and surface modifications options, allowing their application in controlled delivery systems and tissue engineering. This review showed that wounds treated with these materials have been shown to promote the healing by enhanced cellular proliferation, growth and differentiation, and reduced inflammation when applied to in vivo models. Despite the advantages shown by collagenbased dressings and the availability in the market, there are still concerns related to wound contraction and scarring, as mentioned. The high cost of pure collagen, the variability in the physicochemical and degradation properties, which are dependent on the collagen source and processing (Lee et al. 2001a), lead to the use of other natural proteins for wound dressing applications. In addition, the sterilization of collagen constitutes a problem because almost all sterilization methods induce modifications to collagen (Reis et al.
1996). In this way, due to the low cost and the easy process, silk fibroin and keratin are presented as good candidates for wound dressing materials.

\section{References}

Adhirajan N, Shanmugasundaram N, Shanmuganathan S, Babu M (2009) Functionally modified gelatin microspheres impregnated collagen scaffold as novel wound dressing to attenuate the proteases and bacterial growth. Eur J Pharm Sci 36:235-245

Altman GH, Diaz F, Jakuba C, Calabro T, Horan RL, Chen J, Lu H, Richmond J, Kaplan DL (2003) Silk-based biomaterials. Biomaterials 24:401-416

Aper T, Schmidt A, Duchrow M, Bruch HP (2007) Autologous blood vessels engineered from peripheral blood sample. Eur J Vasc Endovasc Surg 33:33-39

Auger F, Rouabhia M, Goulet F, Berthod F, Moulin V, Germain L (1998) Tissue-engineered human skin substitutes developed from collagen-populated hydrated gels: clinical and fundamental applications. Med Biol Eng Comput 36:801-812

Ayad S, Boot-Handford RP, Humphries MJ, Kadler KE, Shuttleworth CA (1994) The extracellular matrix facts book. Academic, London

Balakrishnan B, Jayakrishnan A (2005) Self-cross-linking biopolymers as injectable in situ forming biodegradable scaffolds. Biomaterials 26:3941-3951

Balakrishnan B, Mohanty M, Umashankar PR, Jayakrishnan A (2005) Evaluation of an in situ forming hydrogel wound dressing based on oxidized alginate and gelatin. Biomaterials 26:6335-6342

Balakrishnan B, Mohanty M, Fernandez AC, Mohanan PV, Jayakrishnan A (2006) Evaluation of the effect of incorporation of dibutyryl cyclic adenosine monophosphate in an in situ-forming hydrogel wound dressing based on oxidized alginate and gelatin. Biomaterials 27:1355-1361

Bannasch H, Unterberg T, Föhn M, Weyand B, Horch RE, Stark GB (2008) Cultured keratinocytes in fibrin with decellularised dermis close porcine full-thickness wounds in a single step. Burns 34:1015-1021

Baughman SM, Morey AF, van Geertruyden PH, Radvany MG, Benson AE, Foley JP (2003) Percutaneous transrenal application of fibrin sealant for refractory urinary leak after gunshot wound. J Urol 170:522-523

Bellingham CM, Lillie MA, Gosline JM, Wright GM, Starcher BC, Bailey AJ, Woodhouse KA, Keeley FW (2003) Recombinant human elastin polypeptides self-assemble into biomaterials with elastin-like properties. Biopolymers 70:445-455

Berry D, Harding KG, Stanton MR, Jasani B, Ehrlich HP (1998) Human wound contraction: collagen organization, fibroblasts, and myofibroblasts. Plast Reconstr Surg 102:124-131

Bidwell III GL, Fokt I, Priebe W, Raucher D (2007) Development of elastin-like polypeptide for thermally targeted delivery of doxorubicin. Biochemical Pharmacology 73:620-631

Blanchard CR, Smith RA, Siller-Jackson AJ (2001) Keratinous protein material for wound healing applications and method. United States Patent 6,274,163

Blanchard CR, Timmons SF, Smith RA (2000) Keratin-based hydrogel for biomedical applications and method of production. United States Patent 6,159,496

Boateng JS, Matthews KH, Stevens HN, Eccleston GM (2008) Wound healing dressings and drug delivery systems: a review. J Pharm Sci 97:2892-2923

Bowler PG (1998) The anaerobic and aerobic microbiology of wounds: a review. Wounds 10:170-178 
Bowler PG, Davies BJ (1999) The microbiology of acute and chronic wounds. Wounds 11:72-79

Bowler PG, Duerden BI, Armstrong DG (2001) Wound microbiology and associated approaches to wound management. Clin Microbiol Rev 14:244-269

Breen AM, Dockery P, O'Brien T, Pandit AS (2008) The use of therapeutic gene eNOS delivered via a fibrin scaffold enhances wound healing in a compromised wound model. Biomaterials 29:3143-3151

Breinl F, Baudisch O (1907) The oxidative breaking up of keratin through treatment with hydrogen peroxide. Z Physiol Chem 52:158-169

Buchanan JH (1977) A cystine-rich protein fraction from oxidized alpha-keratin. Biochem J 167:489-491

Buchta C, Hedrich HC, Macher M, Höcker P, Redl H (2005) Biochemical characterization of autologous fibrin sealants produced by CryoSeal ${ }^{\circledR}$ and Vivostat ${ }^{\circledR}$ in comparison to the homologous fibrin sealant product Tissucol/Tisseel ${ }^{\circledR}$. Biomaterials 26:62336241

Chen WYJ, Rogers AA, Lydon MJ (1992) Characterization of biologic properties of wound fluid collected during early stages of wound healing. J Investig Dermatol 99:559-564

Chen G, Liu D, Maruyama N, Ohgushi H, Tanaka J, Tateishi T (2004) Cell adhesion of bone marrow cells, chondrocytes, ligament cells and synovial cells on a PLGA-collagen hybrid mesh. Mater Sci Eng, C 24:867-873

Chen G, Tanaka J, Tateishi T (2006a) Osteochondral tissue engineering using a PLGA-collagen hybrid mesh. Mater Sci Eng, C 26:124-129

Chen YH, Dong WR, Xiao YQ, Zhao BL, Hu GD, An LB (2006b) Preparation and bioactivity of human hair keratin-collagen sponge, a new type of dermal analogue. Nan Fang Yi Ke Da Xue Xue Bao 26:131-138

Chen YH, Dong WR, Chen QY, Zhao BL, Zou ZZ, Xiao YQ, Hu GD, Qiu XX (2007) Biological dressing with human hair keratincollagen sponge-poly 2-hydroxyethyl methacrylate composite promotes burn wound healing in SD rats. Nan Fang Yi Ke Da Xue Xue Bao 27:1621-1626

Chen J-P, Chang G-Y, Chen J-K (2008) Electrospun collagen/chitosan nanofibrous membrane as wound dressing. Colloids Surf, A 313314:183-188

Cowsar DR (2009) Bioactive keratin peptides. US Patent 7,501,485 B2

Crewther WG, Frase RDB, Lennox FG, Lindley H (1965) The chemistry of keratins. In: Anfinsen JCB, Anson ML, Edsall JT, Richards FM (eds) Advances in protein chemistry. Academic, New York, pp 191-346

Cullen B, Watt PW, Lundqvist C, Silcock D, Schmidt RJ, Bogan D, Light ND (2002) The role of oxidised regenerated cellulose/ collagen in chronic wound repair and its potential mechanism of action. Int J Biochem Cell Biol 34:1544-1556

Curran MP, Plosker GL (2002) Bilayered Bioengineered Skin Substitute (Apligraf ${ }^{(\mathbb{R})}$ ): A Review of its Use in the Treatment of Venous Leg Ulcers and Diabetic Foot Ulcers. BioDrugs 16:439455

Cutting KF, White RJ (2002) Maceration of the skin and wound bed 1: its nature and causes. J Wound Care 11:275-278

Daamen WF, Veerkamp JH, van Hest JCM, van Kuppevelt TH (2007) Elastin as a biomaterial for tissue engineering. Biomaterials 28:4378-4398

Dai NT, Williamson MR, Khammo N, Adams EF, Coombes AGA (2004) Composite cell support membranes based on collagen and polycaprolactone for tissue engineering of skin. Biomaterials 25:4263-4271

Dainiak MB, Allan IU, Savina IN, Cornelio L, James ES, James SL, Mikhalovsky SV, Jungvid H, Galaev IY (2010) Gelatinfibrinogen cryogel dermal matrices for wound repair: preparation, optimisation and in vitro study. Biomaterials 31:67-76
Daltrey DC, Rhodes B, Chattwood JG (1981) Investigation into the microbial flora of healing and non-healing decubitus ulcers. J Clin Pathol 34:701-705

De Vries H, Zeegelaar J, Middelkoop E, Gijsbers G, Van Marle J, Wildevuur C, Westerhof W (1995) Reduced wound contraction and scar formation in punch biopsy wounds. Native collagen dermal substitutes. A clinical study. Br J Dermatol 132:690-697

Deng C-M, He L-Z, Zhao M, Yang D, Liu Y (2007) Biological properties of the chitosan-gelatin sponge wound dressing. Carbohydr Polym 69:583-589

Ding C-M, Zhou Y, He Y-N, Tan W-S (2008) Perfusion seeding of collagen-chitosan sponges for dermal tissue engineering. Process Biochem 43:287-296

Doillon CJ (1987) Porous collagen sponge wound dressings: in vivo and in vitro studies. J Biomater Appl 2:562-578

Doillon CJ, Silver FH, Berg RA (1987) Fibroblast growth on a porous collagen sponge containing hyaluronic acid and fibronectin. Biomaterials 8:195-200

Douglas WS, Simpson NB (1995) Guidelines for the management of chronic venous leg ulceration. Report of a multidisciplinary workshop. Br J Dermatol 132:446-452

Drummy LF, Phillips DM, Stone MO, Farmer BL, Naik RR (2005) Thermally induced $\hat{\mathrm{I}} \pm$-helix to $\hat{\mathrm{I}}^{2}$-sheet transition in regenerated silk fibers and films. Biomacromolecules 6:3328-3333

Duca L, Nicolas F, Alain JPA, Bernard H, Laurent D (2004) Elastin as a matrikine. Crit Rev Oncol Hematol 49:235-244

Dunn MW, Nishihara T, Stenzel KH, Branwood AW, Rubin AL (1967) Collagen-derived membrane: corneal implantation. Science 157:1329-1330

Earland C, Knight CS (1956) Structure of keratin II: amino acid content of fractions isolated from oxidized wool. Biochim Biophys Acta 22:405-411

Ehrbar M, Metters A, Zammaretti P, Hubbell JA, Zisch AH (2005) Endothelial cell proliferation and progenitor maturation by fibrinbound VEGF variants with differential susceptibilities to local cellular activity. J Control Release 101:93-109

Enoch S, Leaper DJ (2008) Basic science of wound healing. Surgery (Oxford) 26:31-37

Eyre DR (1980) Collagen: molecular diversity in the body's protein scaffold. Science 207:1315-1322

Falabella AF (2006) Debridement and wound bed preparation. Dermatol Ther 19:317-325

Farahani RMZ (2007) Fibrin/platelet plug counteracts cutaneous wound contraction: the hypothesis of "skipping stone". Med Hypotheses 69:30-32

Faury G (2001) Function-structure relationship of elastic arteries in evolution: from microfibrils to elastin and elastic fibres. Pathol Biol 49:310-325

Feughelmann M (1985) Keratin. In: Kroschwitz JI (ed) Encyclopedia of polymer science and engineering, 2nd edn. Wiley, New York, pp 566-600

Fitton AR, Drew P, Dickson WA (2001) The use of a bilaminate artificial skin substitute (IntegraTM) in acute resurfacing of burns: an early experience. British Journal of Plastic Surgery 54:208-212

Garcia Y, Wilkins B, Collighan RJ, Griffin M, Pandit A (2008) Towards development of a dermal rudiment for enhanced wound healing response. Biomaterials 29:857-868

Gardner SE, Frantz RA, Doebbeling BN (2001) The validity of the clinical signs and symptoms used to identify localized chronic wound infection. Wound Repair Regen 9:178-186

Goddard DR, Michaelis L (1934) A study on keratin. J Biol Chem 106:605-614

Gopinath D, Ahmed MR, Gomathi K, Chitra K, Sehgal PK, Jayakumar R (2004) Dermal wound healing processes with 
curcumin incorporated collagen films. Biomaterials 25:19111917

Grant I, Warwick K, Marshall J, Green C, Martin R (2002) The coapplication of sprayed cultured autologous keratinocytes and autologous fibrin sealant in a porcine wound model. Br J Plast Surg 55:219-227

Gray D, White RJ (2004) The wound exudate continuum: an aid to wound assessment. Wounds UK: Applied Wound Management Supplement, pp 19-21

Griffith BC, Morey AF, Rozanski TA, Harris R, Dalton SR, Torgerson SJ, Partyka SR (2004) Central renal stab wounds: treatment with augmented fibrin sealant in a porcine model. J Urol 171:445-447

Gu S-Y, Wang Z-M, Ren J, Zhang C-Y (2009) Electrospinning of gelatin and gelatin/poly(L-lactide) blend and its characteristics for wound dressing. Mater Sci Eng, C 29:1822-1828

Hafemann B, Ensslen S, Erdmann C, Niedballa R, Zuhlke A, Ghofrani $\mathrm{K}$ (1999) Use of a collagen/elastin-membrane for the tissue engineering of dermis. Burns 25:373-384

Halbert AR, Stacey MC, Rohr JB, Jopp-Mckay A (1992) The effect of bacterial colonization on venous ulcer healing. Australas J Dermatol 33:75-80

Hamasaki S, Tachibana A, Tada D, Yamauchi K, Tanabe T (2008) Fabrication of highly porous keratin sponges by freeze-drying in the presence of calcium alginate beads. Mater Sci Eng, C 28:1250-1254

Harding KG, Morris HL, Patel GK (2002) Healing chronic wounds. BMJ 324:160-163

Harley BAC, Gibson LJ (2008) In vivo and in vitro applications of collagen-GAG scaffolds. Chem Eng J 137:102-121

Hashimoto T, Suzuki Y, Tanihara M, Kakimaru Y, Suzuki K (2004) Development of alginate wound dressings linked with hybrid peptides derived from laminin and elastin. Biomaterials 25:1407-1414

Haslik W, Kamolz L, Nathschläger G, Andel H, Meissl G, Frey M (2007) First experiences with the collagen-elastin matrix Matriderm as a dermal substitute in severe burn injuries of the hand. Burns 33:364-368

Haslik W, Kamolz LP, Manna F, Hladik M, Rath T, Frey M (2010) Management of full-thickness skin defects in the hand and wrist region: first long-term experiences with the dermal matrix Matriderm $^{\circledR}$. JPRAS 63:360-364

Herrero-Vanrell R, Rincón AC, Alonso M, Reboto V, MolinaMartinez IT, Rodríguez-Cabello JC (2005) Self-assembled particles of an elastin-like polymer as vehicles for controlled drug release. J Control Release 102:113-122

Hinek A, Rabinovitch M (1994) $67-\mathrm{kD}$ elastin-binding protein is a protective "companion" of extracellular insoluble elastin and intracellular tropoelastin. J Cell Biol 126:563-574

Hinek A, Wrenn DS, Mecham RP, Barondes SH (1988) The elastin receptor: a galactoside-binding protein. Science 239:1539-1541

Hinek A, Yanting W, Kela L, Thomas FM, Felipe J (2005) Proteolytic digest derived from bovine Ligamentum Nuchae stimulates deposition of new elastin-enriched matrix in cultures and transplants of human dermal fibroblasts. J Dermatol Sci 39:155-166

Hino T, Tanimoto M, Shimabayashi S (2003) Change in secondary structure of silk fibroin during preparation of its microspheres by spray-drying and exposure to humid atmosphere. J Colloid Interface Sci 266:68-73

Hofmann S, Wong Po Foo CT, Rossetti F, Textor M, VunjakNovakovic G, Kaplan DL, Merkle HP, Meinel L (2006) Silk fibroin as an organic polymer for controlled drug delivery. J Control Release 111:219-227

Horan RL, Antle K, Collette AL, Wang Y, Huang J, Moreau JE, Volloch V, Kaplan DL, Altman GH (2005) In vitro degradation of silk fibroin. Biomaterials 26:3385-3393

Hori K, Sotozono C, Hamuro J, Yamasaki K, Kimura Y, Ozeki M, Tabata Y, Kinoshita S (2007) Controlled-release of epidermal growth factor from cationized gelatin hydrogel enhances corneal epithelial wound healing. J Control Release 118:169-176

Huang S, Jin Y, Deng T, Wu H (2006) Wound dressings containing bFGF-impregnated microspheres: preparation, characterization, in vitro and in vivo studies. J Appl Polym Sci 100:4772-4781

Huemmerich D, Slotta U, Scheibel T (2006) Processing and modification of films made from recombinant spider silk proteins. Appl Phys A: Mater Sci Process 82:219-222

Humphries MJ, Komoriya A, Akiyama SK, Olden K, Yamada KM (1987) Identification of two distinct regions of the type III connecting segment of human plasma fibronectin that promote cell type-specific adhesion. J Biol Chem 262:6886-6892

Ikada Y, Tabata Y (1998) Protein release from gelatin matrices. Adv Drug Deliv Rev 31:287-301

Inngjerdingen K, Nergård CS, Diallo D, Mounkoro PP, Paulsen BS (2004) An ethnopharmacological survey of plants used for wound healing in Dogonland, Mali, West Africa. J Ethnopharmacol 92:233-244

Inoue S, Tanaka K, Arisaka F, Kimura S, Ohtomo K, Mizuno S (2000) Silk fibroin of bombyx mori is secreted, assembling a high molecular mass elementary unit consisting of $\mathrm{H}$-chain, Lchain, and P25, with a 6:6:1 molar ratio. J Biol Chem 275:40517-40528

Jacob MP, Robert L (1989) Isolation, characterization and biochemical properties of elastin. CRC, Florida

Jiang W, Wang H, Jin F, Yu C, Chu D, Wang L, Lu X (2008) Improved wound healing in pressure-induced decubitus ulcer with controlled release of basic fibroblast growth factor. J Alloy Comp 459:508-514

Jin H-J, Kaplan DL (2003) Mechanism of silk processing in insects and spiders. Nature 424:1057-1061

Jin HJ, Park J, Karageorgiou V, Kim UJ, Valluzzi R, Cebe P, Kaplan D (2005) Water-stable silk films with reduced $\beta$-sheet content. Adv Funct Mater 15:1241-1247

Jørgensen PH, Jensen KH, Andreassen TT (1987) Mechanical strength in rat skin incisional wounds treated with fibrin sealant. J Surg Res 42:237-241

Kaplan DL, Adams WW, Farmer B, Viney C (1994) Silk-biology, structure, properties and genetics. ACS Symp Ser 544:2-16

Kaplan DL, Mello CM, Arcidiacono S, Fossey S, Senecal K (1998) Silk. In: McGrath K, Canoy DL (eds) Protein based materials. Birkhauser, Boston, pp 103-131

Kawai K, Suzuki S, Tabata Y, Ikada Y, Nishimura Y (2000) Accelerated tissue regeneration through incorporation of basic fibroblast growth factor-impregnated gelatin microspheres into artificial dermis. Biomaterials 21:489-499

Kawai K, Suzuki S, Tabata Y, Nishimura Y (2005) Accelerated wound healing through the incorporation of basic fibroblast growth factor-impregnated gelatin microspheres into artificial dermis using a pressure-induced decubitus ulcer model in genetically diabetic mice. Br J Plast Surg 58:1115-1123

Kearney JN (2001) Clinical evaluation of skin substitutes Burns 27:545-551

Kitajima T, Sakuragi M, Hasuda H, Ozu T, Ito Y (2009) A chimeric epidermal growth factor with fibrin affinity promotes repair of injured keratinocyte sheets. Acta Biomater 5:2623-2632

Kuehn BM (2007) Chronic wound care guidelines issued. JAMA 297:938-939

Kuijpers AJ, van Wachem PB, van Luyn MJA, Plantinga JA, Engbers GHM, Krijgsveld J, Zaat SAJ, Dankert J, Feijen J (2000) In vivo compatibility and degradation of crosslinked gelatin gels incorporated in knitted Dacron. J Biomed Mater Res 51:136-145

Kumar MS, Kirubanandan S, Sripriya R, Sehgal PK (2010) Triphala incorporated collagen sponge - a smart biomaterial for infected dermal wound healing. J Surg Res 158:162-170 
Lamme EN, de Vries HJ, van Veen H, Gabbiani G, Westerhof W, Middelkoop E (1996) Extracellular matrix characterization during healing of full-thickness wounds treated with a collagen/ elastin dermal substitute shows improved skin regeneration in pigs. J Histochem Cytochem 44:1311-1322

Lamme EN, van Leeuwen RTJ, Jonker A, van Marle J, Middelkoop E (1998) Living skin substitutes: survival and function of fibroblasts seeded in a dermal substitute in experimental wounds. J Invest Dermatol 111:989-995

Lazarus GS, Cooper DM, Knighton DR, Margolis DJ, Pecoraro RE, Rodeheaver G, Robson MC (1994) Definitions and guidelines for assessment of wounds and evaluation of healing. Arch Dermatol 130:489-493

Le Nihouannen D, Guehennec LL, Rouillon T, Pilet P, Bilban M, Layrolle P, Daculsi G (2006) Micro-architecture of calcium phosphate granules and fibrin glue composites for bone tissue engineering. Biomaterials 27:2716-2722

Lee CH, Singla A, Lee Y (2001a) Biomedical applications of collagen. Int J Pharm 221:1-22

Lee J, Macosko CW, Urry DW (2001b) Elastomeric polypentapeptides cross-linked into matrixes and fibers. Biomacromolecules 2:170-179

Lee J, Macosko CW, Urry DW (2001c) Mechanical properties of cross-linked synthetic elastomeric polypentapeptides. Macromolecules 34:5968-5974

Liu S-J, Kaua Y-C, Choua C-Y, Chenc J-K, Wud R-C, Yeh W-L (2010) Electrospun PLGA/collagen nanofibrous membrane as early-stage wound dressing. J Membr Sci 355:53-59

Long JL, Tranquillo RT (2003) Elastic fiber production in cardiovascular tissue-equivalents. Matrix Biol 22:339-350

Lu Q, Hu X, Wang X, Kluge JA, Lu S, Cebe P, Kaplan DL (2010) Water-insoluble silk films with silk I structure. Acta Biomater 6:1380-1387

Maclaren JA (1962) The extent of reduction of wool proteins by thiols. Aust J Chem 15:824-831

Madsen K, Moskalewski S, von der Mark K, Friberg U (1983) Synthesis of proteoglycans, collagen, and elastin by cultures of rabbit auricular chondrocytes - relation to age of the donor. Dev Biol 96:63-73

Man G, Lei R, Ting W, Li-Ping S, Ling-Rong L, Qi-Qing Z (2007) Potential wound dressing with improved antimicrobial property. J Appl Polym Sci 105:1679-1686

Mandal BB, Kapoor S, Kundu SC (2009a) Silk fibroin/polyacrylamide semi-interpenetrating network hydrogels for controlled drug release. Biomaterials 30:2826-2836

Mandal BB, Priya AS, Kundu SC (2009b) Novel silk sericin/gelatin 3D scaffolds and 2-D films: fabrication and characterization for potential tissue engineering applications. Acta Biomater 5:30073020

Martyn C, Greenwald S (2001) A hypothesis about a mechanism for the programming of blood pressure and vascular disease in early life. Clin Exp Pharmacol Physiol 28:948-951

McClure MJ, Sell SA, Simpson DG, Walpoth BH, Bowlin GL (2010) A three-layered electrospun matrix to mimic native arterial architecture using polycaprolactone, elastin, and collagen: a preliminary study. Acta Biomater 6:2422-2433

Mcdevitt JP, Tyrrell DJ (2002) Removal of targeted proteases with proteinaceous wound dressings. United States Patent 2002/ 0156437 A1

Mecham RP, Madaras J, McDonald JA, Ryan U (1983) Elastin production by cultured calf pulmonary artery endothelial cells. J Cell Physiol 116:282-288

Mensah AY, Houghton PJ, Dickson RA, Fleischer TC, Heinrich M, Bremner P (2006) In vitro evaluation of effects of two Ghanaian plants relevant to wound healing. Phytother Res 20:941-944
Michel D, Harmand M-F (1990) Fibrin seal in wound healing: effect of thrombin and $\left[\mathrm{Ca}^{2+}\right]$ on human skin fibroblast growth and collagen production. J Dermatol Sci 1:325-333

Mithieux SM, Rasko JEJ, Weiss ASAS (2004) Synthetic elastin hydrogels derived from massive elastic assemblies of selforganized human protein monomers. Biomaterials 25:49214927

Morey AF, Anema JG, Harris R, Gresham V, Daniels R, Knight RW, Beall D, Macphee M, Cornum RL (2001) Treatment of grade 4 renal stab wounds with absorbable fibrin adhesive bandage in a porcine model. J Urol 165:955-958

Moy LR, Lee A, Zalka A (1991) Commonly used suture materials in skin surgery. Am Fam Physician 44:2123-2128

Negri AP, Cornell HJ, Rivett DE (1993) A Model for the Surface of Keratin Fibers. Textile Research Journal 63:109-115

Neidert MR, Lee ES, Oegema TR, Tranquillo RT (2002) Enhanced fibrin remodeling in vitro with TGF-[beta]1, insulin and plasmin for improved tissue-equivalents. Biomaterials 23:3717-3731

Nicholas JP (2002) Classification of wounds and their management. Surgery 20:114-117

O'Brien FJ, Harley BA, Yannas IV, Gibson L (2004) Influence of freezing rate on pore structure in freeze-dried collagen-GAG scaffolds. Biomaterials 25:1077-1086

O'Donnell IJ, Thompson EOP (1964) Studies on reduced wool IV: the isolation of a major component. Aust J Biol Sci 17:973-989

Oju J, Soo Hyun R, Ji Hyung C, Kim B-S (2005) Control of basic fibroblast growth factor release from fibrin gel with heparin and concentrations of fibrinogen and thrombin. J Control Release 105:249-259

Okabayashi R, Nakamura M, Okabayashi T, Tanaka Y, Nagai A, Yamashita K (2009) Efficacy of polarized hydroxyapatite and silk fibroin composite dressing gel on epidermal recovery from full-thickness skin wounds. Journal of Biomedical Materials Research Part B: Applied Biomaterials 90B:641-646

Ono I, Tateshita T, Inoue M (1998) Effect of a collagen matrix containing epidermal growth factor on wound contraction. Wound Repair Regen 6:213-222

Ono I, Tateshita T, Inoue M (1999) Effects of a collagen matrix containing basic fibroblast growth factor on wound contraction. J Biomed Mater Res 48:621-630

Panilaitis B, Altman GH, Chen J, Jin H-J, Karageorgiou V, Kaplan DL (2003) Macrophage responses to silk. Biomaterials 24:30793085

Parry DAD, Steinert PM (1992) Intermediate filament structure. Curr Opin Cell Biol 4:94-98

Partridge SM, Davis HF, Adair GS (1955) The chemistry of connective tissues. 2. Soluble proteins derived from partial hydrolysis of elastin. Biochem J 61:11-21

Pasquali-Ronchetti I, Baccarani-Contri M (1997) Elastic fiber during development and aging. Microsc Res Tech 38:428-435

Plowman JE (2003) Proteomic database of wool components. J Chromatogr B 787:63-76

Powell HM, Boyce ST (2007) Wound closure with EDC cross-linked cultured skin substitutes grafted to athymic mice. Biomaterials 28:1084-1092

Powell HM, Supp DM, Boyce ST (2008) Influence of electrospun collagen on wound contraction of engineered skin substitutes. Biomaterials 29:834-843

Purna SK, Babu M (2000) Collagen based dressings - a review. Burns 26:54-62

Queen D, Orsted H, Sanada H, Sussman G (2004) A dressing history. Int Wound J 1:59-77

Reguera J, Fahmi A, Moriarty P, Girotti A, Rodríguez-Cabello JC (2004) Nanopore formation by self-assembly of the model genetically engineered elastin-like polymer [(VPGVG)2 (VPGEG)(VPGVG)2]15. J Am Chem Soc 126:13212-13213 
Reis RL, Cunha AM, Allan PS, Bevis MJ (1996) Mechanical behavior of injection-molded starch-based polymers. Polym Adv Technol 7:784-790

Rho KS, Jeong L, Lee G, Seo B-M, Park YJ, Hong S-D, Roh S, Cho JJ, Park WH, Min B-M (2006) Electrospinning of collagen nanofibers: effects on the behavior of normal human keratinocytes and early-stage wound healing. Biomaterials 27:1452-1461

Rosenbloom J, Abrams WR, Mecham R (1993) Extracellular matrix 4: the elastic fiber. FASEB J 7:1208-1218

Ross R, Bornstein P (1969) The elastic fiber. J Cell Biol 40:366-381

Rossitch E, Bullard DE, Oakes WJ (1987) Delayed foreign-body reaction to silk sutures in pediatric neurosurgical patients. Childs Nerv Syst 3:375-378

Ruszczak Z (2003) Effect of collagen matrices on dermal wound healing. Adv Drug Deliv Rev 55:1595-1611

Sanjay R, Mancy M, Brijesh S (2009) The Efficacy of Collagen Membrane as a Biodegradable Wound Dressing Material for Surgical Defects of Oral Mucosa: A Prospective Study. Journal of oral and maxillofacial surgery: official journal of the American Association of Oral and Maxillofacial Surgeons 67:1600-1606

Schantz J-T, Brandwood A, Hutmacher D, Khor H, Bittner K (2005) Osteogenic differentiation of mesenchymal progenitor cells in computer designed fibrin-polymer-ceramic scaffolds manufactured by fused deposition modeling. J Mater Sci Mater Med 16:807-819

Schmoekel H, Schense JC, Weber FE, Grätz KW, Gnägi D, Müller R, Hubbell JA (2004) Bone healing in the rat and dog with nonglycosylated BMP-2 demonstrating low solubility in fibrin matrices. J Orthop Res 22:376-381

Schneider A, Wang XY, Kaplan DL, Garlick JA, Egles C (2009) Biofunctionalized electrospun silk mats as a topical bioactive dressing for accelerated wound healing. Acta Biomaterialia 5:2570-2578

Schönfelder U, Abel M, Wiegand C, Klemm D, Elsner P. Hipler U-C (2005) Influence of selected wound dressings on PMN elastase in chronic wound fluid and their antioxidative potential in vitro. Biomaterials 26:6664-6673

Sehgal SC, Arunkumar BK (1992) Microbial flora and its significance in pathology of sickle cell disease leg ulcers. Infection 20:86-88

Shettigar UR, Jagannathan R, Natarajan R (1982) Collagen film for burn wound dressings reconstituted from animal intestines. Artif Organs 6:256-260

Smith DJ (1995) Use of Biobrane in wound management. J Burn Care Rehabil 16:317-320

Still J, Glat P, Silverstein P, Griswold J, Mozingo D (2003) The use of a collagen sponge/living cell composite material to treat donor sites in burn patients Burns 29:837-841

Strodtbeck F (2001) Physiology of wound healing. Newborn Infant Nurs Rev 1:43-52

Tachibana A, Furuta Y, Takeshima H, Tanabe T, Yamauchi K (2002) Fabrication of wool keratin sponge scaffolds for long-term cell cultivation. J Biotechnol 93:165-170

Thilagar S, Jothi NA, Omar ARS, Kamaruddin MY, Ganabadi S (2009) Effect of keratin-gelatin and bFGF-gelatin composite film as a sandwich layer for full-thickness skin mesh graft in experimental dogs. J Biomed Mater Res B Appl Biomater 88B: $12-16$

Thomas S (2004) Wound and wound healing. Wound management and dressings. Pharmaceutical Press, London

Thomas W, Arastoo R, Martina K, Lubos S, Thomas E (2010) Basics in nutrition and wound healing. Nutrition 26:862-866

Tsubouchi K (2001) Wound dressing material containing silk fibroin and sericin as main component and method for preparing the same. United States Patent 6175053
Ulubayram K, Cakar AN, Korkusuz P, Ertan C, Hasirci N (2001) EGF containing gelatin-based wound dressings. Biomaterials 22:1345-1356

Um IC, Kweon H, Park YH, Hudson S (2001) Structural characteristics and properties of the regenerated silk fibroin prepared from formic acid. Int J Biol Macromol 29:91-97

Unger RE, Wolf M, Peters K, Motta A, Migliaresi C, James Kirkpatrick C (2004) Growth of human cells on a non-woven silk fibroin net: a potential for use in tissue engineering. Biomaterials 25:1069-1075

Urry DW (1997) Physical chemistry of biological free energy transduction as demonstrated by elastic protein-based polymers. J Phys Chem B 101:11007-11028

Vachon DJ, Yager DR (2006) Novel sulfonated hydrogel composite with the ability to inhibit proteases and bacterial growth. J Biomed Mater Res A 76A:35-43

Van Dyke M (2008) Wound healing compositions containing keratin biomaterials. Patent US20280274165

Van Dyke ME, Blanchard CR, Timmons SF, Siller-Jackson AJ, Smith RA (2001a) Soluble keratin peptides. United States Patent $6,270,791 \mathrm{~B} 1$

Van Dyke ME, Timmons SF, Blanchard CR, Siller-Jackson AJ, Smith RA (2001b) Absorbent keratin wound dressing. United States Patent 6,270,793B1

van Zuijlen PPM, Lamme EN, van Galen MJM, van Marle J, Kreis RW, Middelkoop E (2002) Long-term results of a clinical trial on dermal substitution. A light microscopy and fourier analysis based evaluation. Burns 28:151-160

Vasconcelos A, Freddi G, Cavaco-Paulo A (2008) Biodegradable materials based on silk fibroin and keratin. Biomacromolecules 9:1299-1305

Verma V, Verma P, Ray P, Ray AR (2008) Preparation of scaffolds from human hair proteins for tissue-engineering applications. Biomed Mater 3:025007

Vollrath F, Knight DP (2001) Liquid crystalline spinning of spider silk. Nature 410:541-548

Wang T-W, Sun J-S, Wu H-C, Tsuang Y-H, Wang W-H, Lin F-H (2006) The effect of gelatin-chondroitin sulfate-hyaluronic acid skin substitute on wound healing in SCID mice. Biomaterials 27:5689-5697

Wang X, Wenk E, Matsumoto A, Meinel L, Li C, Kaplan DL (2007) Silk microspheres for encapsulation and controlled release. J Control Release 117:360-370

Wang W, Lin S, Xiao Y, Huang Y, Tan Y, Cai L, Li X (2008a) Acceleration of diabetic wound healing with chitosan-crosslinked collagen sponge containing recombinant human acidic fibroblast growth factor in healing-impaired STZ diabetic rats. Life Sci 82:190-204

Wang Y, Rudym DD, Walsh A, Abrahamsen L, Kim H-J, Kim HS, Kirker-Head C, Kaplan DL (2008b) In vivo degradation of three-dimensional silk fibroin scaffolds. Biomaterials 29:3415-3428

Wechselberger G, Russell RC, Neumeister MW, Schoeller T, PizaKatzer H, Rainer C (2002) Successful transplantation of three tissue-engineered cell types using capsule induction technique and fibrin glue as a delivery vehicle. Plast Reconstr Surg 110:123-129

Willerth SM, Arendas KJ, Gottlieb DI, Sakiyama-Elbert SE (2006) Optimization of fibrin scaffolds for differentiation of murine embryonic stem cells into neural lineage cells. Biomaterials 27:5990-6003

Winkler S, Kaplan DL (2000) Molecular biology of spider silk. Rev Mol Biotechnol 74:85-93

Wong Po Foo C, Kaplan DL (2002) Genetic engineering of fibrous proteins: spider dragline silk and collagen. Adv Drug Deliv Rev 54:1131-1143 
Wood SA, Lemons JE, Prasad KU, Urry DW (1986) In vitro calcification and in vivo biocompatibility of the cross-linked polypentapeptide of elastin. J Biomed Mater Res 20:315-335

Wright E, McMillan R, Cooper A, Apkarian R, Conticello V (2002) Thermoplastic elastomer hydrogels via self-assembly of an elastinmimetic triblock polypeptide. Adv Funct Mater 12:149-154

Wu Z, Sheng Z, Sun T, Geng M, Li J, Yao Y, Huang Z (2003) Preparation of collagen-based materials for wound dressing. Chin Med J 116:419-423

Yamamoto M, Ikada Y, Tabata Y (2001) Controlled release of growth factors based on biodegradation of gelatin hydrogel. J Biomater Sci Polym Ed 12:77-88

Yang C, Hillas PJ, Báez JA, Nokelainen M, Balan J, Tang J, Spiro R, Polarek JW (2004) The application of recombinant human collagen in tissue engineering. BioDrugs 18:103-119

Yang C, Xu L, Zhou Y, Zhang X, Huang X, Wang M, Han Y, Zhai M, Wei $\mathrm{S}$, Li J (2010) A green fabrication approach of gelatin/CM-chitosan hybrid hydrogel for wound healing. Carbohydr Polym 82:1297-1305
Yao CH, Liu BS, Hsu SH, Chen YS, Tsai CC (2004) Biocompatibility and biodegradation of a bone composite containing tricalcium phosphate and genipin crosslinked gelatin. J Biomed Mater Res A 69A:709-717

Yücel EA, Oral O, Olgaç V, Oral CK (2003) Effects of fibrin glue on wound healing in oral cavity. J Dent 31:569-575

Zhang Y-Q (2002) Applications of natural silk protein sericin in biomaterials. Biotechnol Adv 20:91-100

Zhong SP, Zhang YZ, Lim CT (2010) Tissue scaffolds for skin wound healing and dermal reconstruction. Wiley Interdiscip Rev Nanomed Nanobiotechnol 2:510-525

Zhou C-Z, Confalonieri F, Medina N, Zivanovic Y, Esnault C, Yang T, Jacquet M, Janin J, Duguet M, Perasso R, Li Z-G (2000) Fine organization of Bombyx mori fibroin heavy chain gene. Nucl Acids Res 28:2413-2419

Zhou CZ, Confalonieri F, Jacquet M, Perasso R, Li ZG, Janin J (2001) Silk fibroin: structural implications of a remarkable amino acid sequence. Proteins 44:119-122 